\title{
Evolving An E-Governance System for Local Self-Government Institutions for Transparency and Accountability
}

\author{
Balakumaran P.J \\ Research Scholar, Department of Computer Science, \\ Sree Saraswathi Thyagaraja College, Pollachi-642107, Coimbatore, India \\ Email: blkumarn@gmail.com \\ Vignesh Ramamoorthy. $\mathrm{H}$ \\ Assistant Professor, Department of Computer Science, \\ Sree Saraswathi Thyagaraja College, Pollachi-642107, Coimbatore, India \\ Email: hvigneshram@gmail.com
}

\begin{abstract}
Panchayati Raj Act came into existence in 1993 and it paved the way for a strong and effective decentralized administrative system in India. The Indian Constitution added 11th schedule to it detailing 29 subjects which are devolved to the local self-government institutions [LSGIs]. It is nearly two decades passed and still LSGIs are hesitant to adapt with their roles to develop them as self-sufficient administrating regions. The devolved function is not fully exercised by the LSGIs. The transferred the departments connected with the 29 subjects are still working in a bureaucratic manner. This study reveals the real reasons behind the poor performance of LSGIs and coming up with a technological solution to overcome the problem through an interactive E-Governance system. Even though 29 subjects are given to the LSGIs, 4 departments are considered in this research due to time constrains.
\end{abstract}

Index Terms - Decentralize, Governance, LSGI, Bureaucratic, Constitution.

\section{Introduction}

Panchayat Raj is a system of governance in which Gram Panchayats are the basic units of administration. It has 3 tiers: village, block and district. The term "Panchayat raj" is relatively new, having originated during the British administration. Raj literally means "governance or government". Mahatma Gandhi advocated Panchayati Raj, a decentralized form of Government where each village is responsible for its own affairs, as the foundation of India's political system. The term for such a vision was Gram Swaraj. The 73rd constitution amendment provided with the uniform pattern of three tier local self-government institution throughout. According to the new system, the Panchayats are given wider powers and responsibilities and it ushered a new era in the field of local governance. The Eleventh schedule of the constitution that was incorporated after the 73rd amendment identifiers 29 areas over which local self-government institution legally have authority. Many of these such as Agriculture, including agricultural extension, Land improvement, implementation of land reforms, land consolidation and soil conservation, Minor irrigation, water management and watershed development, Animal husbandry, dairying and poultry, Fisheries, Social forestry and farm forestry, Minor forest produce, Small scale industries, including food processing industries, Khadi, village and cottage industries, Rural housing, Drinking water, Fuel and fodder, Roads, culverts, bridges, ferries, waterways and other means of communication, Rural electrification, including distribution of electricity, Non-conventional energy sources, Poverty alleviation programme, Education, including primary and secondary schools, Technical training and vocational education, Adult and non-formal education, Libraries, Cultural activities, Markets and fairs, Health and sanitation, including hospitals, primary health centers and dispensaries, Family welfare, Women and child development, Social welfare, including welfare of the handicapped and mentally retarded, Welfare of the weaker sections, and in particular, of the Scheduled Castes and the Scheduled Tribes, Public distribution system, Maintenance of community assets [1] [2] [3].

\subsection{Background of PRIs in Tamil Nadu}

The Tamil Nadu Panchayats Act 1994 came about following the 73rd Central Amendment to the constitution. This act replaced the system that was prevalent under the Tamil Nadu Panchayat Act, 1958 wherein a two-tier system of Village Panchayats and Panchayat Unions existed. The Village Panchayat Presidents became ex-officio members of the Panchayat Union with the Chairperson of Panchayat Union being elected directly.

Some of the important changes brought about by the 73rd Amendment to the Constitution and the Tamil Nadu Panchayats Act 1994 are listed below:

- Introduction of a three tier system - at the Village, Intermediate (Block) and District levels. 
- Mandatory conduct of Local Body elections every five years and conduct of elections before the expiry of the duration of the Local Body or before the expiry of a period of 6 months from the date of its dissolution.

- Introduction of reservation of seats and offices for Scheduled Castes/Scheduled Tribes in proportion to their population in every Local Body with provision for rotation of the reserved seats and offices.

- Introduction of reservation of one-third of total number of seats and offices for women with provision for rotation.

- Constitution of a State Election Commission as an independent body to conduct elections to both rural and urban Local Bodies regularly.

- Establishment of a State Finance Commission to recommend devolution of resources from the State Government to the rural and urban Local Bodies.

- Constitution of a District Planning Committee to consolidate the plans prepared by the rural and urban Local Bodies in the district with a view to prepare a comprehensive development plan for the district [4].

The remainder of this paper is organized as follows: Section 2 gives the background study of our work. Section 3 describes the research methodology used. Section 4 presents the data analysis. Conclusion and future work are given in the final section.

\section{Background Study}

\subsection{Research Problem}

Even after the establishment of 3 tier PRI system in the country, many States find it difficult to carry out the exhaustive list of functions assigned to them through 11th schedule. E-Governance already exists in government sector in various forms like, accessing property, taxes and rendering basic services. EGovernance can be applied to bring transparency in local administration as an effective channel of communication between Panchayats, line department wings and public. This will empower the Panchayats to understand their role in implementing local governance. This system will help the public to know about their rights and it will enhance the quality of public service by the departments and Panchayat.

\subsection{Objectives}

The chief objective of this research is to identify existing problems in the functioning of transferred institutions under the local self-government system called Panchayat raj so that to evolve a suitable technological solution to rectify these problems.

- Internal Process Improvement.

- Improved Decision Making.

- Transparency \& Accountability.

- Improved Service Delivery to Citizens.
Specific objectives of e-Governance are,

- To study the functions of Panchayat and departments.

- Identify the gap pertaining to the rules and responsibilities of transferred institutions.

- Identify effective channels to communicate between Panchayat, Transferred institutions and People.

- To develop suitable e-Governance tools for local self-governments.

But e-Governance system was not experimented in local self-government system to coordinate the 29 functions carried out by different departments in our Panchayat area. This research is an attempt to integrate e-Governance in a novel manner to coordinate the functions of different line departments in a Panchayat area through the Panchayat to enable them to provide maximum benefits to the people.

\subsection{Need for e-Governance in Panchayati Raj}

In democratic States, administrators will be elected by the people. In India the Prime Minister and the cabinet ate the administrators and the same system has been implemented in the States as Chief Minister and ministers. In order to bring this kind of administration to gross root level local self-government system has been established. Even though India adopted local selfgovernment system during 1950 but the lack of effective functioning resulted it as a failure. In order to empower local self-government system, government of India passed the 73 rd amendment to the Constitution and made separate provisions for rural local self-government system in the country one more have been included to the Constitution. But in Tamilnadu elected representatives of local self-government could not implement their full responsibilities and it acts as a hurdle in the process of effective local self-government administrator lack of effective communication between the public, Panchayat and the government departments lead to various problem [5].

\section{Research Methodology}

\subsection{Introduction}

An extensive literature review was conducted to understand various dimensions of the research problem. National and international journals, periodicals, books and internet were used to gather knowledge on the subject. 73rd Constitutional Amendment, Schedule 11 of the Indian Constitution, Tamilnadu Panchayati Raj Act, Policy Note of TN Government, research studies on the subject by eminent scholars were also scanned for the study. It gave a clear picture of the existing Laws and programmers regarding Panchayati Raj and the eGovernance tools, processes and methods. The literature review helped to evolve innovative idea to create a new system for better governance of local self- government institutions. Objectives of the study was framed with the aim to realize the goal of establishing a creative net 
working to coordinate different public service agencies within a Panchayat to accelerate its developmental activities through Panchayat and to disseminate its full benefits to all citizens in a village Research design was carefully done as it is an attempt to develop creative solution to smoothen the functioning of local selfgovernment institutions. Primary and Secondary data were taken to analyze the existing situation and desired situation. Gap identification and suitable remedial measures were evolved with detailed analysis. Collected data were analyzed and interpreted to create an innovative mechanism with technological tools. This research study is an attempt to empower local selfgovernment institutions and to coordinate various functions of different agent.

\subsection{E-Governance and Data warehousing}

Data warehouse is a subject-oriented, integrated, timevariant, non-volatile collection of data, cutting across the enterprise. Until there is a repository of accurate data across the enterprise value chain, application of mining tools to analyze and aid in strategic government decisions is impossible. At times, government departments might come across shortages of resources in one department and excess of resources in the other. This could be due to non-availability of proper data and facilities to disseminate information. Even if government departments are computerized and networked more for the purpose of Internet usage and mail transfer, the information available in one department, which possess the data might not be utilized by other departments. This is because the information is stored in different formats, in different platforms and in heterogeneous data base systems. A look at the information requirements at each level and the information flow across levels shows a pattern. This pattern makes the entire vertical domain of e-Governance framework, an ideal domain for development of data warehousing and use of data mining applications [5].

\subsection{E-Governance and Data mining}

Data mining is a broad category of applications and technologies for gathering, storing, analyzing and providing access to data to help the decision makers in making decisions. Typically, a Data Warehouse and Mining (DWM) application includes large data warehouse, decision support systems, query and reporting, On Line Analytical Process (OLAP), statistical analysis, forecasting and mining (a technology to extract unknown and hidden patterns and knowledge from within the data). DWM, therefore is well suited for eGovernance applications in the G2G (Government to Government) and G2C (Government to Citizen) environment. For effective implementation of a DWM solution, the de facto condition is a solid and reliable data warehouse on available e-Governance data from different sources. Data Mining has been successfully deployed in numerous application areas. Within the government the focus of data mining is predominantly on the management of interaction between the government and citizen or business. In these application data mining can extract knowledge from transactional data, can lower the burden of dealing with large volume of transactions and can improve decision making abilities [5].

\subsection{Proposed System}

For above type of applications voluminous data will be thrown that can only be handled by using data warehousing techniques. The following section will propose the possible implementation of the technological solution to the local self-government institution. The proposal is based on the literature review, and the brief background study of Panchayats in India and Tamil Nadu State, findings on the gap between the government department and the Panchayat. And a suitable technological solution was framed to solve the problems in this field. Various tools are used to develop this technological solution. Activities of different line department offices transferred under Panchayats to provide services to the people are collected and complied to form a full-fledged record and developed as an interactive technological support system to bring transparency and accountability in the local selfgovernment system. The E-Governance shall be implemented in the transferred institution as an interactive web enabled system. The transferred institution can have an insight on the real functions of these departments and rectify the problem. EGovernance can be applied to bring transparency in local administration as an effective channel to communicate between Panchayats, departments and public. This will empower the Panchayat to understand their role in implementing local governance. This system will help the public to know about their rights and it will enhance the quality of public service by the departments of Panchayat. Overall this is to understand the function of transferred institution and identify the gaps so as to evolve an innovative technological solution to make the system effective for public.

\subsection{Architecture of Data Warehouse for Panchayat}

A data warehouse brings together data from multiple operational (internal) and external data sources into common physically separated repository. The data stored in the warehouse are uploaded from the operational systems. The data may pass through an operational data store for additional operations before they are used in the DW for reporting. Data warehousing technology is becoming essential for effective business intelligence, business strategy formulation and implementation in a globally competitive environment, wherein larger and larger amounts of data are required to be processed faster and faster for comprehension of its real meaning and impact. Data warehousing enables easy organization and maintenance of large data in addition to fast retrieval and analysis in the manner and depth required from time to time [5]. The main purpose of the data warehouse is to serve as a centre of these four departments such as Education, Agriculture, Primary Health Center and 
animal Husbandry. The services, schemes and plans of the four departments are connected with the Panchayat for delivering better services to the people. In order to understand the services of the departments, citizen charter shall be prepared by the departments and it shall be disseminated to the public through Panchayat along with the schemes and programs. This can be made using the data warehouse techniques. In this e-Governance is covered by these departments' activities. The Data Warehouse acts as a hub, to facilitate the exchange of information between systems and therefore serves as the enterprise information infrastructure. The accessibility, transparency, efficiency and impact of e-Governance service will be automatically evaluated, which will produce a large amount of data. We propose a architectural framework of data warehouse which is expected to meet the demand of the data storage needed by e-Governance application.

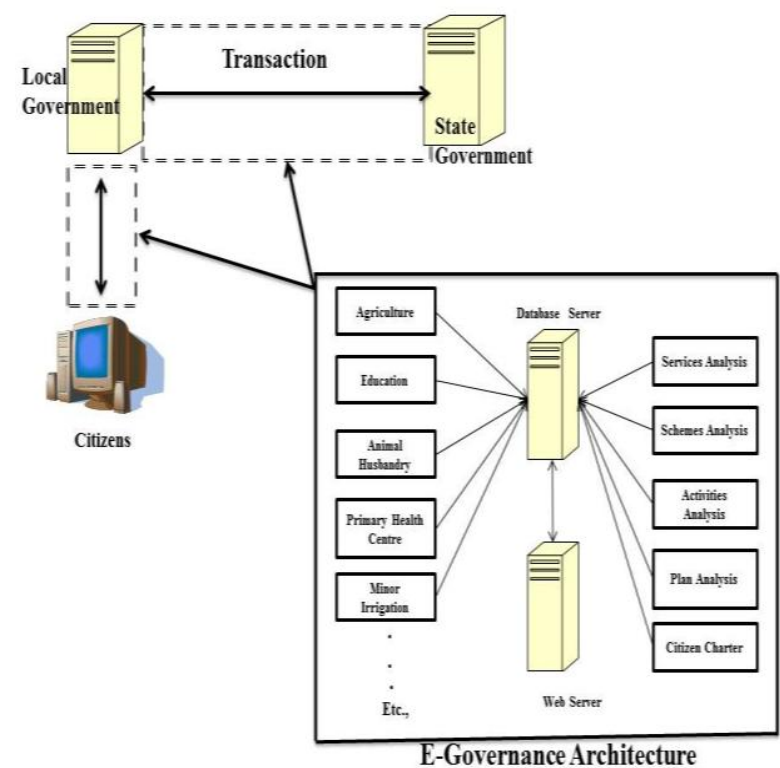

Figure 1. E-Governance Architecture

\subsection{Processes in E-Governance}

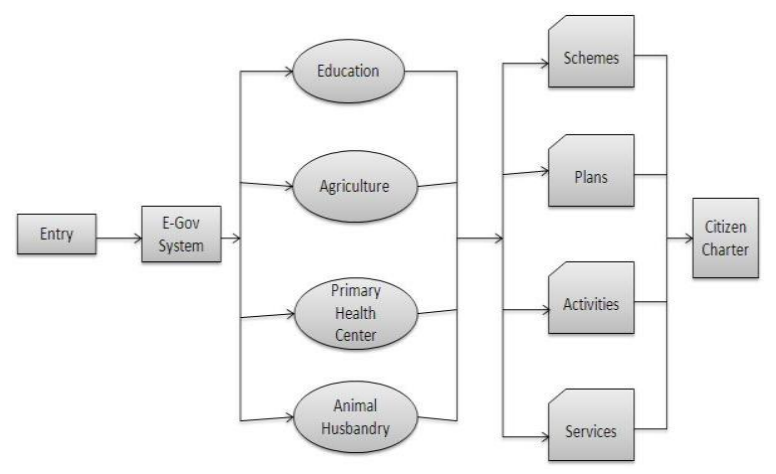

Figure 2. Processes of E-Governance
In this e-Governance system the dataflow into the mandatory functions of the departments shall be listed out and avail to the public as citizen's charter. The citizen charter means it conveys the overall process in simple manner and illustrates it to the public. Then the public easily understand the government department activities and easily know their rights. It defines the rules and responsibilities of a government department which explains its services to the public. Each and every department should prepare the citizen charter so that it will create a proper understanding of its function for the benefit of society.

\section{Data Analysis}

\subsection{Introduction}

Panchayat should carry out different activities related to the 29 subjects included in $11^{\text {th }}$ schedule as per $73^{\text {rd }}$ Constitution Amendment Act. Though Panchayat plays a vital role in certain mandatory functions related to civic amenities, public utilities, taxes etc., but still it is not capable enough to extend its activities towards the goal of achieving overall development of the Panchayat by implementing activities related to the 29 subjects enshrined in the $11^{\text {th }}$ Schedule as per the $73^{\text {rd }}$ Constitutional Amendment. This study limits it preview in 4 sectors namely Education, Primary Health, Animal Husbandry and Agriculture due to time constrains. These are the mandatory subjects on which the Panchayats are responsible to provide services. The study concentrates mainly on these sectors due to the significance of these on the life of people in the rural area. The research findings reveal that the Panchayats are not giving ample importance to these basic areas where they have to stress their attention.

\subsection{Developing E-Governance}

This research used .NET 3.0 Framework with 2GB of RAM, 80GB of Hard Disk and the processor speed of $2.8 \mathrm{GHz}$ to develop the E-Governance system. The system contains more than 100 forms integrated into the E-Governance system. The forms are integrated by using the Content Manager method. The Content Manager is a scalable solution for storing and retrieving documents of various types. The Content Manager stores data on distributed servers and provides single point access.

\subsubsection{E-Governance System}

E-Governance system provides a common platform for departments and public to communicate their ideas and needs simultaneously. E-Governance is used in many varieties to render services to the people like they can access different application forms through concerned department websites. It also disseminates information to the public regarding government activities. In-spite of all these developments, lack of a transparent E-Governance system is obvious and this study aims to develop an innovative version of E-Governance which will bring transparency and accountability in local self-government 
system. This is an attempt to create a full- fledged EGovernance system interlinked with the Panchayat and the transferred institutions and thereby providing a platform for public to utilize the resources in a proper way. This will ensure maximum services to the people. Panchayat can exercise its monitoring function over the activities of the transferred institution and can provide better services to people. This E-Governance system will give a space to the Panchayat to plan and implement integrated projects and schemes with the active participation of the departments and public. This will give an opportunity to the public to share their views, requirements and complaints with the Panchayat and the transferred institutions. This is a novel idea and it can be applied in different fields for transparency and accountability. This system provides ample space to the Panchayat to have control and monitoring over the departments under the Panchayat like Agriculture, Primary Health Centre, Education and Animal Husbandry to ensure its better performance in servicing the public. The Master Page of this system contains the Home, About Panchayat, Panchayat Process, Departments Page, Schemes details, Panchayat Contact details and Panchayat Related Links. There are 3 Content Managers are used in this Panchayat Master Page. Each Content Manager is used to control the overall transaction process of this E-Governance system.

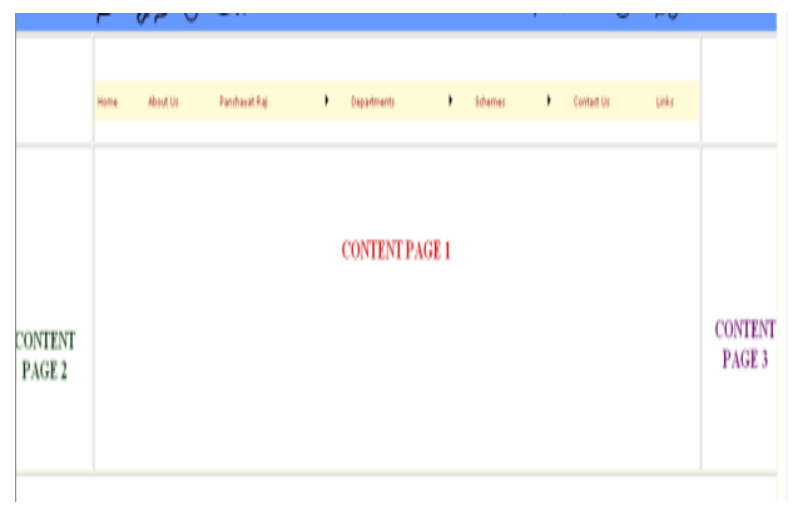

Figure 3. E-Governance System

\subsection{Panchayat System}

The 'Panchayat System' is one of the processes in this E-Governance system. The 'Panchayat System' is one of the processes in this E-Governance system. The Panchayat monitors overall processes of each department. Content manager controls the departmental activities under the 'Panchayat System'. The Panchayat system contains the following processes like Home, Panchayat Services, Panchayat Schemes, Public Complaint Register, Public Complaint Status, Ask questions to Panchayat, Public Charter details, Panchayat Contact details and Panchayat related links. This will integrate the overall departmental transactions like 'Complaint Register' and 'Public Charter'.

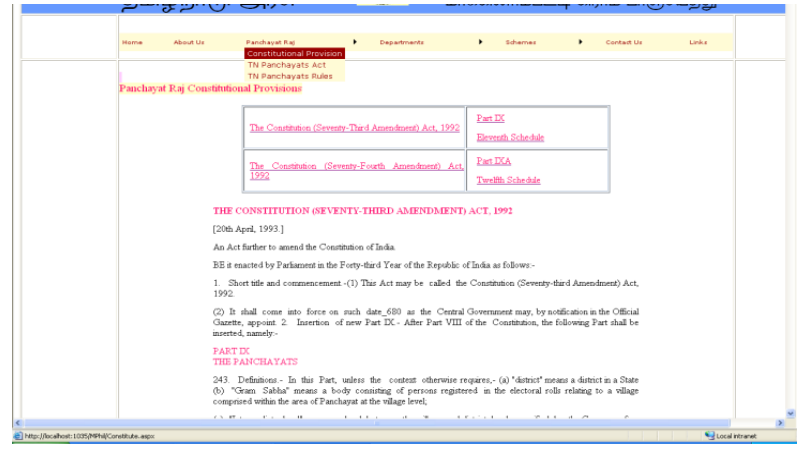

Figure 4. Server Page 1

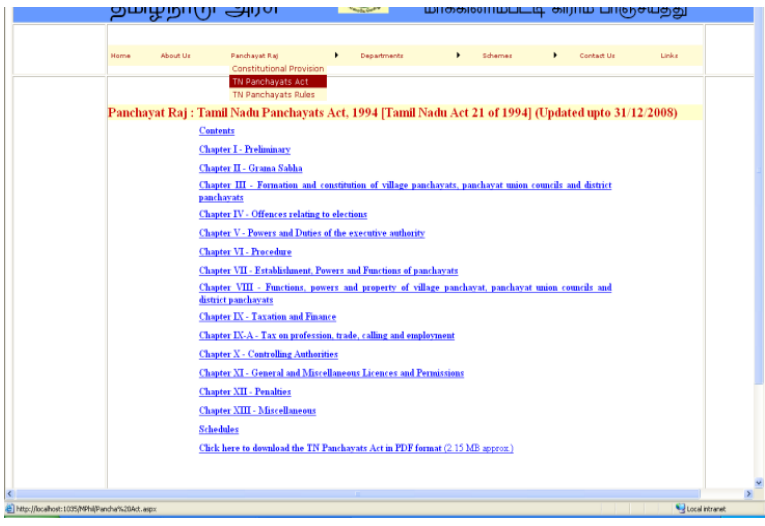

Figure 5. Server Page 2

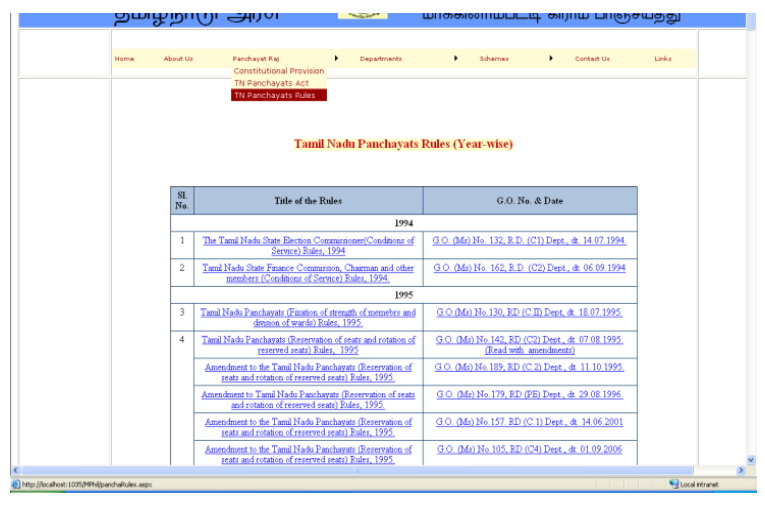

Figure 6. Server Page 3

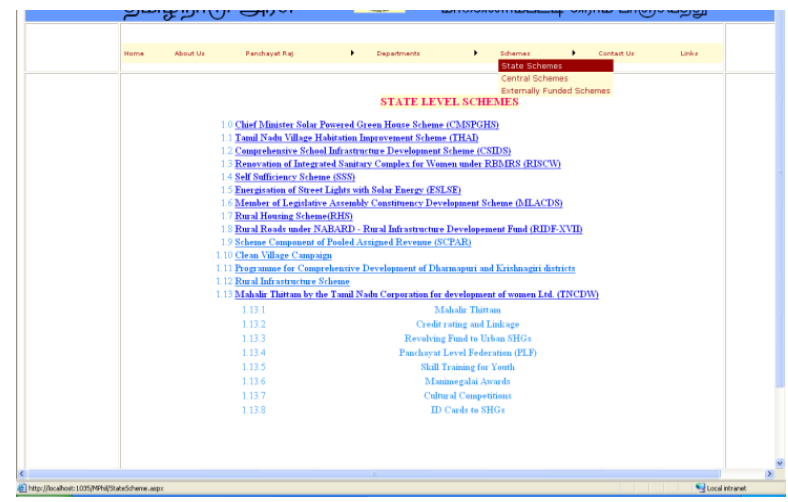

Figure 7. Server Page 3 


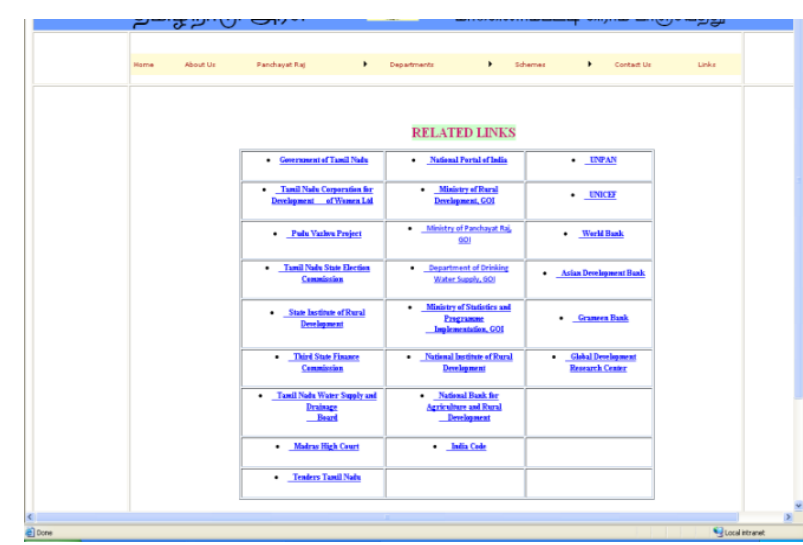

Figure 8. Server Page 4

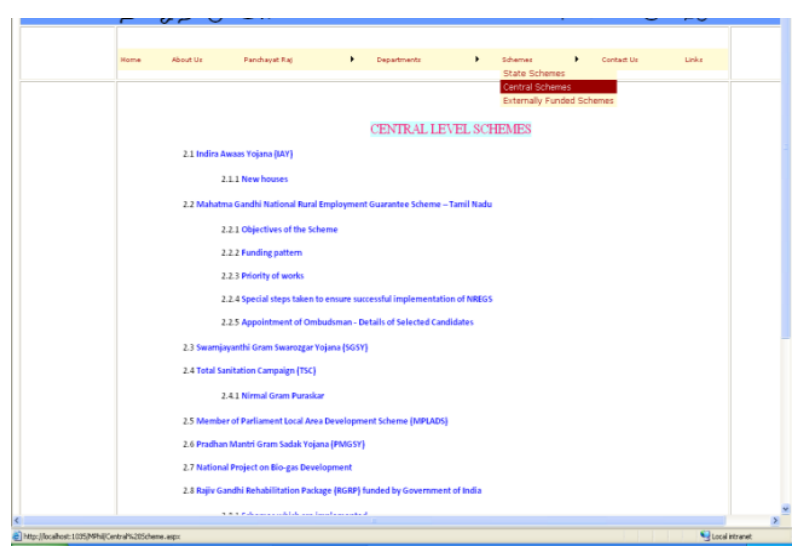

Figure 9. Server Page 5

The user can access the system easily by login into the 'Panchayat System' by using her/his Public ID and Password. In this, details are retrieving from the Panchayat main database using the queries. The Panchayat 'Authentication Page' checks the validity of the user ID and Password before giving permission to access the 'Panchayat System' and its processes.

\section{Conclusion}

Existing Panchayat system could not address the different problems in its area. Renovation of EGovernance system which will cater to the needs of the public as well as address crucial problems in each Panchayat is a must. The proposed E-Governance system will interlink the Panchayat, the department and the public without deterring the functions of each unit. The development of this technological tool will function as a common platform for the Panchayat department and the public to improve the local administration activities as well as to provide maximum services to the people. Implementation of this tool will answer the problems of various developmental and welfare programs of the Panchayat and will bring prospective development in local economy. This tool can be replicated in different sectors, for example, in between ministries, Government, States and departments. Effective utilization of this tool will enhance the transparency and accountability of administrators, departments, bureaucrats and public there by capacitate the nation to grow upwards in the progress map. The E-Governance system will enhance the subsidiaries of government organizations and will bring efficiency and transparency in administration. The existing administrative system faces various problems in handling complaints, implementing schemes, and exercising administrative functions etc. This is due to the problem of accumulated massive data and there is a lack of proper system to prioritize and classify the data as per the needs and significance of the system. A well systematized and channelized E-Governance system can only identify ways and means to implement the government activities in a smart manner. Implementing the E-Governance application in Panchayat system will produce voluminous data storage. This data can be utilized for later records and references.

\section{References}

[1] Abhishek Jain, Vikram Singh Rana," Implementing E-Government", 3rd International Conference on E-Governance ICEG2005, December 9-11, 2005.

[2] Amod Kumar, Amarpal Singh and Amit Shukla,'LOKVANI: AN Effort to Empower Citizens", 3rd International Conference on EGovernance ICEG2005, December 9-11, 2005.

[3] Anita Karwal, Shri J.N.Singh and Neeta Shah,"EGovernance and Citizens' Charter: An Agenda for an Effective Devlivery Mechanism- The Ahmedabad Experience", 3rd International Conference on E-Governance ICEG2005, December 9-11, 2005.

[4] "ePRI study project report" for Panchayat raj Institution in State of Tamilnadu by National Informatics Centre Services Inc. November, 2009.

[5] Prateek Bhanti, Urmani Kaushal and Archana Pandey,"E-Governance in Higher Education: Concept and Role of Data Warehousing Techniques", International Journal of Computer Applications (0975 - 8887), Volume 18- No.1, March 2011.

[6] Prof. T.P. Rama Rao,'ICT and e-Governance for Rural Development", Center for Electronic Governance, Indian Institute of Management, Ahmadabad.

[7] Shabbir Ahmad and Liaquat Majeed,'Implementing E-Government", 3rd International Conference on E-Governance ICEG2005, December 9-11, 2005.

[8] Shampa Paul,"A case study of E-governance initiatives in India", The International Information \& Library Review, Volume 39, Issues 3-4, September-December 2007. 


\section{Authors' Profiles}

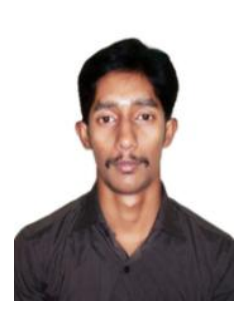

P.J. Balakumaran received his M.Phil in Computer Science from Sree Saraswathi Thyagaraja College, Pollachi in 2012, M.Sc Computer Science in Sree Ramu College of Arts and Science, Pollachi in 2011. He is currently pursuing his Ph.D in Computer Science at Sree Saraswathi Thyagaraja College, Pollachi, TN, Coimbatore District. He has presented papers in National and International Conferences. His areas of interest are Data Warehousing and Mining, E Governance and Web designing.

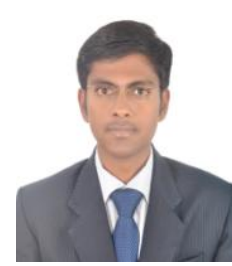

H. Vignesh Ramamoorthy received his M.Sc (Software Engineering) from Dr.Mahalingam College of Engineering and Technology (affiliated to Anna University, Chennai) in 2010, MCA from Bharathiar University in 2012, Post Graduate Diploma in Mobile Computing from Annamalai University in 2012, Post Graduate Diploma in English Language Teaching from Annamalai University in 2013. He completed his M.Phil (part time) in Computer Science at Sree Saraswathi Thyagaraja College, Pollachi in the year 2013. He is currently working as an Assistant Professor of Computer Science in Sree Saraswathi Thyagaraja College, Pollachi, Coimbatore District, TN, India. He has presented more than 17 papers in National and International Conferences and has 13 publications in various reputed journals. His areas of interests are Data Mining, E Governance and Mobile Computing. 